\title{
Tipe Kepribadian Bigfive Dengan Pengambilan Keputusan Dalam Memilih Parfum di Kota Pekanbaru
}

\author{
${ }^{1}$ Bima Maulana Putra ${ }^{2}$ Fikri ${ }^{3}$ Suroyo \\ ${ }^{1}$ Psikologi Universitas Islam Riau ${ }^{2}$ Dosen Psikologi Universitas Islam Riau \\ ${ }^{3}$ Dosen Pendidikan Sejarah Universitas Riau \\ 1Bimamaulanaputra98@gmail.com²fikri@psy.uir.ac.id ${ }^{3}$ Suroyokajian123@gmail.com
}

\begin{abstract}
Decision making in buying a product is a difficult thing for consumers, because it really depends on the type of personality which belongs to consumers. Several studies explain that the personality type of big five is a variable that could influence decision making. The aim of this research is to explain the correlation between personality types of bigfive with decision making in choosing perfumes. The research population is perfume consumers in Pekanbaru Mall with a total of 400 consumers. Data were collected using BigFive Personality inventory scale and Decision Making scale. The sample was taken using accidental sampling technique. The analysis technique that was used in this research is Product Moment correlation test analysis techniques. Based on the analysis, there is correlation between Bigfive personality and decision making in choosing perfumes with a correlation value ( $r)$ of $(0.839)$ with a significant value ( $p$ ) of $(0.035)(p<0.050)$. The hypothesis of this research is accepted, which means there is positive and significant correlation between personality type of bigfive and decision making in choosing perfumes. The effective contribution of BigFive Personality with Decision Making is $32.9 \%$
\end{abstract}

Keywords: bigfive personality, decision making, perfume.

\section{PENDAHULUAN}

Zaman globalisasi sekarang ini, banyak individu menganggap penggunaan parfum sebagai salah satu kebutuhan utama bagi sebagian orang, salah satunya sebagai penambah daya tarik. Tidak heran jika banyak parfum dari berbagai merek dan jenis menjadi pilihan utama sebagian orang yang menganggap diri mereka sebagai konsumen 'penggila parfum'. Penggunaan parfum juga dinilai penting untuk menunjang penampilan, ketika menghadiri suatu acara atau bahkan kegiatan. Seseorang akan merasa tidak tampil percaya diri dihadapan publik jika tidak menggunakan parfum. Namun, banyak dari parfum berubah menjadi aroma yang berbeda dari sebelumnya, dikarenakan perubahan aroma parfum akan berubah tergantung dengan tipe cairan dari tubuh individu yang menggunakan parfum.

Pengambilan keputusan juga menjadi sesuatu yang penting untuk memilih parfum, hal ini juga berpengaruh pada persepsi individu terhadap kepribadian pemakai parfum itu sendiri. Kualitas dalam pengambilan keputusan juga dinilai penting dan menjadi kunci dalam pemilihan parfum. (Krestin 2016). Dilansir dari
CIMO pada tahun 2007, pemilihan keputusan juga dinilai harus memiliki sebuah strategi ataupun penilaian khusus dalam memilih suatu objek, hal ini biasanya diterapkan dalam perusahaan ataupun organisasi dalam bidang yang besar seperti sebuah perilaku organisasi.

Kepribadian tidak hanya membahas mengenai coping dan behaving, melainkan juga membahas mengenai feeling dan thinking. Individu tidak hanya memiliki satu jenis kepribadian saja, dalam diri individu telah ada berbagai jenis karakteristik dalam diri. Diantaranya ialah pemarah, egois, kreatif, ingin tahu, aktif, humoris, curiga, dan sejenisnya. Beberapa karakteristik tersebut dibentuk menjadi 5 (lima) karakteristik utama yaitu Openness, Conscientiousness, Extraversion, Agreeableness, dan Neuroticism yang sering disingkat dengan kata O-C-E-A-N. (Sabine 2015)

Mendapati fenomena di lapangan yang berada pada penjualan parfum, karakter Openness lebih mudah mengambil keputusan diantara keempat faktor lainnya. Faktor Neuroticsm merupakan karakter paling sulit dalam mengambil keputusan. Selain itu, Extraversion dan Agreeableness merupakan dua faktor yang 
mengambil keputusan menggunakan alasan rasional seperti meninjau jenis produk dan harga produk. Terakhir yaitu Conscientiousness memiliki karakter yang lebih rumit dalam mengambil keputusan. Karakter ini biasanya lebih menggunakan perasaan daripada pemikiran rasional. Selain itu, dalam pengamatan di beberapa toko parfum di Kota Pekanbaru, tampak para konsumen lebih mempertimbangkan varian aroma parfum, hal ini cenderung membuat konsumen lebih sulit dalam mengambil keputusan dalam membeli parfum, terutama dalam pilihan seperti wangi parfum, merek parfum, harga parfum dan kemasan parfum itu sendiri. Berdasarkan permasalahan yang ada, maka dapat diambil sebuah rumusan masalahyaitu ada atau tidak hubungan antara tipe kepribadian Big Five dengan pengambilan keputusan dalam memilih parfum (Amira 2016).

\section{METODE PENELITIAN}

Jenis penelitian ini adalah penlitian kuantitatif dengan jenis penelitian deskriptif. Big Five Personality merupakan suatu kepribadian yang bisa memprediksi dan menjelaskan perilaku individu. Hal ini merupakan pendekatan yang dapat digunakan oleh para peneliti untuk melihat kepribadian yang telah dibentuk dengan menggunakan analisis lima faktor. Big Five Personality diukur menggunakan skala kepribadian lima faktor yang diambil dari teori McCrae dan Costa (1998) dengan aspek Extraversion, Agreeableness, Conscientiousness, Neuroticism, dan Openness.

Penulis mengambil data kependudukan dari Badan Pusat Statistik Kota Pekanbaru tahun 2018 pada Kecamatan Senapelan, Kelurahan Sago sebanyak 2,018 Jiwa, Maka, didapatkan hasil sejumlah 399.80 dimana, penulis membulatkan hasil bilangan menjadi 400 sampel, dengan menggunakan rumus Slovin. Dalam penelitian ini, penulis mengambil sampel dengan menggunakan teknik Accidental Sampling, yang diambil secara acak dan kebetulan. Sugiyono (2010) menjelaskan jika teknik ini merupakan teknik pengambilan sampel populasi dimana peneliti menjumpai sampel pada tempat penelitian dengan keadaan tertentu.

Setelah melakukan penelitian sekaligus mengumpulkan data, langkah selanjutnya yaitu proses analisis data. Sebelum melakukan proses analisis korelasi, penulis terlebih dahulu dilakukan uji normalitas atau sebaran data sekaligus uji linieritas hubungan variabel sebagai prasyarat dalam melakukan analisis korelasi pada Product Moment. Korelasi product moment juga digunakan untuk mencari arah atau kekuatan hubungan antara variabel bebas dengan variabel terikat, sehingga data berbentuk interval dan rasio (Siregar, 2013) perhitungan analisis dilakukan dengan program komputer SPSS 17.00.

Data yang diambil pada penelitian ini ialah data yang dihasilkan dari penyebaran skala Big Five Personality dan skala pengambilan keputusan yang disebarkan kepada 400 masyarakat kota Pekanbaru yang sedang membeli parfum di pusat perbelanjaan Mall Pekanbaru, dimana para sampel akan diberikan sebuah skala dalam bentuk paper and pencil dalam sebuah angket yang memudahkan sampel dalam mengisi skala. Dengan menggunakan dua buah variabel yaitu variabel bebas (X) Big Five Personality dan variabel terikat (Y) Pengambilan keputusan. Adapun data dari variabel bebas dan terikat diambil dari penelitian terdahulu dan jurnal-jurnal terkait.

Jika sebaran normal, artinya tidak terdapat perbedaan signifikan antara variabel bebas dengan variable terikat kurva. Hasil yang dipakai jika $p>$ 0.05 maka sebaran normal, sebaliknya jika $p \leq$ 0.05 maka sebaran tidak normal. Teknik uji normal yang digunakan adalah Kolmogorov smirnof $-Z$ (Sugiyono, 2010). Uji liniearitas hubungan dilakukan antara variabel BigFive Personality dengan Pengambilan keputusan. Untuk melihat apakah linier atau tidak pada hubungan kedua variabel. Penulis menggunakan uji linieritas. Dengan melihat nilai $p$ pada tabel Deviation from Linierty. Jika $p \leq 0.05$ maka terdapat hubungan linier, tetapi jika $p>0.05$ maka tidak terdapat hubungan linier. Setelah melakukan uji asumsi, penulis selanjutnya dilakukan uji hipotesis korelasi paerson product moment dari Pearson yang telah dikemukakan sebelumnya. Proses perhitungan uji prasyarat maupun uji hipotesis dilakukan menggunakan program statistik SPSS 17.0.

\section{HASIL DAN PEMBAHASAN}

Penulis menggunakan skala BigFive Personality Inventory dengan jumlah aitem sebanyak 44 dan aspek sebanyak lima buah yaitu openness, extraversion, neuroticsm, conscientiousness, dan agreeableness yang telah 
diadaptasi dalam bahasa Indonesia sebelumnya oleh peneliti terdahulu dengan tingkat valitidas alat tes lebih tinggi dari 0.50 . Sedangkan untuk skala Pengambilan Keputusan, penulis mengunakan skala yang telah ada yaitu skala yang dibuat oleh Suci (2016) dengan item berjumlah 29. Tingkat validitas pada alat tes pengambilan keputusan juga lebih tinggi dari 0.50 .

Tabel 1

Deskripsi Data Penelitian

\begin{tabular}{ccccccccc}
\hline & \multicolumn{3}{c}{ skor $\mathbf{X}$ yg diperoleh } & (Empirik) & \multicolumn{4}{c}{$\begin{array}{c}\text { Skor yang dimungkinkan } \\
\text { (Hipotetik) }\end{array}$} \\
Variabel Penelitian & $\begin{array}{c}\text { X } \\
\text { Min }\end{array}$ & $\begin{array}{c}\text { Max } \\
\text { Xax }\end{array}$ & Mean & SD & $\begin{array}{c}\text { X } \\
\text { Min }\end{array}$ & $\begin{array}{c}\text { X } \\
\text { Max }\end{array}$ & Mean & SD \\
\hline $\begin{array}{c}\text { BigFive Personality } \\
\begin{array}{c}\text { Pengambilan } \\
\text { Keputusan }\end{array}\end{array}$ & 128 & 150 & 139.58 & 6.926 & 44 & 220 & 132 & 29.33 \\
\hline
\end{tabular}

Pada nilai empirik, didapatkan nilai ratarata senilai 139.58 untuk skala bigfive personality dan nilai 74.68 untuk skala pengambilan keputusan dengan standar deviasi setinggi 6.926 untuk skala bigfive personality dan 5.810 untuk skala pengambilan keputusan. Pada nilai hipotetik, didapatkan nilai rata-rata senilai 132 untuk skala bigfive personality dan 72.5 untuk skala pengambilan keputusan. Sedangkan nilai standar deviasi setinggi 29.33 untuk skala bigfive personality dan 14.5 untuk skala pengambilan keputusan.

Penulis lalu mengelompokkan menjadi 5 (lima) kategori yaitu, rendah, sedang, berdasarkan hasil rata-rata dan standar deviasi, data persentase bisa dilihat dalam tabel dibawah ini:

Tabel 2

Kategori skala BigFive Personality

\begin{tabular}{ccccc}
\hline Variabel & Kategori & Kriteria & Frekuensi & $\begin{array}{c}\text { Persentase } \\
\text { (\%) }\end{array}$ \\
\hline BigFive Personality & Sangat Tinggi & $\mathrm{X} \geq 150$ & 21 & $5.3 \%$ \\
& Tinggi & $143 \leq \mathrm{X}<149$ & 117 & $29.3 \%$ \\
& Sedang & $136 \leq \mathrm{X}<143$ & 187 & $46.8 \%$ \\
& Rendah & $129 \leq \mathrm{X}<136$ & 57 & $14.3 \%$ \\
& SangatRendah & $\mathrm{X} 129$ & 18 & $4.5 \%$ \\
& Jumlah & & $\mathbf{4 0 0}$ & $\mathbf{1 0 0 \%}$ \\
\hline
\end{tabular}

Berdasarkan kategorisasi BigFive Personality pada tabel diatas menunjukkan bahwa jumlah terbanyak yaitu terdiri dari 187 orang yang terletak pada kategori sedang dari jumlah keseluruhan 400 partisipan dengan persentase 46.8 $\%$ dari $100 \%$.

Tabel 3

Kategori skala Pengambilan Keputusan

\begin{tabular}{ccccc}
\hline Variabel & Kategori & Kriteria & Frekuensi & $\begin{array}{c}\text { Persentase } \\
(\mathbf{\%})\end{array}$ \\
\hline Pengambilan & Sangat Tinggi & $\mathrm{X} \geq 89$ & 11 & $2.8 \%$ \\
Keputusan & Tinggi & $77 \leq \mathrm{X}<83$ & 117 & $29.3 \%$ \\
& Sedang & $71 \leq \mathrm{X}<77$ & 114 & $28.5 \%$ \\
& Rendah & $65 \leq \mathrm{X}<71$ & 94 & $23.5 \%$ \\
& SangatRendah & $\mathrm{X} 65$ & 64 & $16 \%$ \\
& Jumlah & & $\mathbf{4 0 0}$ & $\mathbf{1 0 0 \%}$ \\
\hline
\end{tabular}


Berdasarkan kategorisasi Pengambilan Keputusan pada tabel diatas menunjukkan bahwa jumlah terbanyak yaitu terdiri dari 117 orang yang terletak pada kategori tinggi dari jumlah keseluruhan 400 partisipan dengan persentase 29.3 $\%$ dari $100 \%$

Pada penelitian ini, penulis mengumpulkan data sebanyak 400 sampel yang berada di Kecamatan Senapelan, kelurahan Sago, dimana populasi menurut Badan Statistik Kota Pekanbaru tahun 2018 sebanyak 2018 penduduk. Penulis menggunakan rumus Slovin untuk mencari berapa banyak jumlah sampel yang harus diteliti, sehingga penulis mendapatkan jumlah 400 sampel.

Tabel 4

Tabel Usia

\begin{tabular}{ccc}
\hline Usia & Jumlah & Persentase \\
\hline $\mathbf{1 8}$ & 46 & $11.5 \%$ \\
$\mathbf{1 9}$ & 59 & $14.8 \%$ \\
$\mathbf{2 0}$ & 57 & $14.3 \%$ \\
$\mathbf{2 1}$ & 28 & $7 \%$ \\
$\mathbf{2 2}$ & 48 & $12 \%$ \\
$\mathbf{2 3}$ & 87 & $21.8 \%$ \\
$\mathbf{2 4}$ & 29 & $7.3 \%$ \\
$\mathbf{2 5}$ & 46 & $11.5 \%$ \\
Total & $\mathbf{4 0 0}$ & \\
\hline
\end{tabular}

Tabel 5

Tabel Jenis Kelamin

\begin{tabular}{ccc}
\hline Jenis Kelamin & Jumlah & Persentase \\
\hline Laki-Laki & 172 & $43.0 \%$ \\
Perempuan & 228 & $57.0 \%$ \\
Total & $\mathbf{4 0 0}$ & \\
\hline
\end{tabular}

Tabel 6

Tabel Pekerjaan

\begin{tabular}{ccc}
\hline Jenis Kelamin & Jumlah & Persentase \\
\hline Mahasiswa & 135 & $33.8 \%$ \\
Pegawa Negeri Sipil & 110 & $27.5 \%$ \\
Pegawai Swasta & 110 & $27.5 \%$ \\
Tidak Bekerja & 45 & $11.3 \%$ \\
Total & $\mathbf{4 0 0}$ & \\
\hline
\end{tabular}

Tabel 7

Tabel Normalitas Kolmogorov-Smirnov

\begin{tabular}{cccc}
\hline Variabel & KZ & $\boldsymbol{P}$ & Keterangan \\
\hline $\begin{array}{c}\text { Pengambilan } \\
\text { Keputusan }\end{array}$ & 0.133 & 0.124 & Normal \\
Bigfive Personality & 0.128 & 0.156 & Normal \\
\hline
\end{tabular}

Berdasarkan hasil tabel diatas, menunjukkan bahwa data variabel bigfive personality berdistribusi normal, dengan $p=0.156$ $(p>0.05)$ sedangkan variabel pengambilan keputusan berdistribusi normal dengan $p=0.124$ $(p>0.05)$, maka penulis menarik kesimpulan, bahwa kedua data diatas menunjukkan data yang berdistribusi normal.

Berdasarkan uji linearitas dengan bantuan program SPSS 17.0 for windows, ditemukan nilai F sebesar 2.443 dengan $P$ sebesar $0.387(p>0.05)$ sehingga dapat diambil kesimpulan bahwa variabel dalam penelitian ini adalah linier.

Tabel 8

Tabel data distribusi Linearitas

\begin{tabular}{cccc}
\hline Variabel & $\begin{array}{c}\text { Liniearitas } \\
(\mathbf{F})\end{array}$ & Sig. & $\begin{array}{c}\text { Ketera } \\
\text { ngan }\end{array}$ \\
\hline $\begin{array}{c}\text { Bigfive Personality } \\
\text { Pengambilan } \\
\text { Keputusan }\end{array}$ & 2.443 & 0.387 & Linear \\
& & & \\
\hline
\end{tabular}

Teknik analisis data untuk menguji hipotesis pada penelitian ini menggunakan korelasi product moment dengan bantuan program SPSS 17.0 for Windows. 
Tabel 9

Nilai Signifikansi Bigfive Personality

\begin{tabular}{cccc}
\hline & & Pengambilan Keputusan & BigFive Personality \\
\hline \multirow{3}{*}{ Big Five Personality } & Korelasi Koefisien & & 0.839 \\
& Sig. (2- tailed) & & 0.035 \\
& N & 400 & 400 \\
Pengambilan Keputusan & Korelasi Koefisien & 0.839 & \\
& Sig. (2-tailed) & 0.035 & \\
& N & 400 & 400 \\
\hline
\end{tabular}

Berdasarkan tabel 4.10 diketahui bahwa nilai koefisien korelasi positif sebesar 0.839 dengan taraf signifikan $(\mathrm{p})$ senilai $0.035(\mathrm{p}<0.05)$ sehingga hipotesis yang diajukan penulis dapat diterima karena terdapat hubungan positif yang signifikan antara variabel BigFive Personality dengan Pengambilan Keputusan Dalam Memilih Parfum. Terlihat nilai koefisien korelasi paerson dengan nilai 0.839 , hal ini menunjukkan jika korelasi positif antara BigFive personality dengan Pengambilan Keputusan memiliki korelasi yang sangat kuat.

Tabel 10

Nilai Signifikansi BigFive Personality Openness

\begin{tabular}{cccc}
\hline & & Pengambilan Keputusan & $\begin{array}{c}\text { BigFive Personality } \\
\text { Openness }\end{array}$ \\
\hline BigFive & Korelasi Koefisien & & 0.600 \\
Personality Openness & Sig. (2- tailed) & & 0.045 \\
& N & 400 & 400 \\
& Korelasi Koefisien & 0.600 & \\
Pengambilan Keputusan & Sig. (2-tailed) & 0.045 & 400 \\
& N & 400 & \\
\hline
\end{tabular}

Berdasarkan tabel 4.11 diketahui bahwa nilai koefisien korelasi positif sebesar 0.600 dengan taraf signifikan $(\mathrm{p})$ senilai $0.045(\mathrm{p}<0.05)$ sehingga hipotesis yang diajukan penulis dapat diterima karena terdapat hubungan positif yang signifikan antara variabel BigFive Personality Openness dengan Pengambilan Keputusan Dalam
Memilih Parfum. Terlihat nilai signifikansi korelasi paerson dengan nilai 0.600 , hal ini menunjukkan jika korelasi antara BigFive personality Openness dengan Pengambilan Keputusan memiliki korelasi yang kuat.

Tabel 11

Nilai Signifikansi BigFive Personality Consciousness

\begin{tabular}{|c|c|c|c|}
\hline & & Pengambilan Keputusan & $\begin{array}{c}\text { BigFive Personality } \\
\text { Conscientiousness }\end{array}$ \\
\hline BigFive & Korelasi Koefisien & & 0.514 \\
\hline Personality & Sig. (2- tailed) & & 0.015 \\
\hline Conscientiousnes & $\mathrm{N}$ & 400 & 400 \\
\hline \multirow{3}{*}{ Pengambilan Keputusan } & Korelasi Koefisien & 0.514 & \\
\hline & Sig. (2-tailed) & 0.015 & \\
\hline & $\mathrm{N}$ & 400 & 400 \\
\hline
\end{tabular}


Berdasarkan tabel 4.12 diketahui bahwa nilai koefisien korelasi positif sebesar 0.514 dengan taraf signifikan (p) senilai 0.015 ( $\mathrm{p}<$ 0.05 ) sehingga hipotesis yang diajukan penulis dapat diterima karena terdapat hubungan positif yang signifikan antara variabel BigFive Personality Conscientiousness dengan
Pengambilan Keputusan Dalam Memilih Parfum. Terlihat nilai signifikansi korelasi Pearson dengan nilai 0.514 , hal ini menunjukkan jika korelasi antara BigFive personality Conscientiousness dengan Pengambilan Keputusan memiliki korelasi yang sedang.

Tabel 12

Nilai Signifikansi BigFive Personality Extraversion

\begin{tabular}{cccc}
\hline & & Pengambilan Keputusan & $\begin{array}{c}\text { BigFive Personality } \\
\text { Extraversion }\end{array}$ \\
\hline BigFive & Korelasi Koefisien & & 0.542 \\
Personality Extraversion & Sig. (2- tailed) & & 0.040 \\
& N & 400 & 400 \\
Pengambilan Keputusan & Korelasi Koefisien & 0.542 & \\
& Sig. (2-tailed) & 0.040 & 400 \\
\hline
\end{tabular}

Berdasarkan tabel 4.13 diketahui bahwa nilai koefisien korelasi positif sebesar 0.542 dengan taraf signifikan (p) senilai $0.040(\mathrm{p}<$ 0.05 ) sehingga hipotesis yang diajukan penulis dapat diterima karena terdapat hubungan positif yang signifikan antara variabel BigFive Personality Extraversion dengan Pengambilan Keputusan Dalam Memilih Parfum. Terlihat nilai signifikansi korelasi paerson dengan nilai 0.542 .

Tabel 13

Nilai Signifikansi BigFive Personality Agreeableness

\begin{tabular}{cccc}
\hline & & $\begin{array}{c}\text { Pengambilan } \\
\text { Keputusan }\end{array}$ & $\begin{array}{c}\text { BigFive Personality } \\
\text { Agreeableness }\end{array}$ \\
\hline BigFive & Korelasi Koefisien & & 0.551 \\
Personality & Sig. (2- tailed) & & 0.002 \\
Agreeableness & N & 400 & 400 \\
& Korelasi Koefisien & 0.551 & \\
Pengambilan Keputusan & Sig. (2-tailed) & 0.002 & 400 \\
& $\mathrm{~N}$ & 400 & \\
\hline
\end{tabular}

Berdasarkan tabel 4.14 diketahui bahwa nilai koefisien korelasi positif sebesar 0.551 dengan taraf signifikan (p) senilai 0.002 (p < 0.05) sehingga hipotesis yang diajukan penulis dapat diterima karena terdapat hubungan positif yang signifikan antara variabel BigFive Personality Agreeableness dengan Pengambilan
Keputusan Dalam Memilih Parfum. Terlihat nilai signifikansi korelasi Pearson dengan nilai 0.551, hal ini menunjukkan jika korelasi antara BigFive personality Agreeableness dengan Pengambilan Keputusan memiliki korelasi yang sedang. 
Tabel 14

Nilai Signifikansi Neuroticsm

\begin{tabular}{cccc}
\hline & & $\begin{array}{c}\text { Pengambilan } \\
\text { Keputusan }\end{array}$ & $\begin{array}{c}\text { BigFive Personality } \\
\text { Neuroticsm }\end{array}$ \\
\hline BigFive & Korelasi Koefisien & & 0.561 \\
Personality Neuroticsm & Sig. (2- tailed) & & 0.022 \\
& N & 400 & 400 \\
& Korelasi Koefisien & 0.561 & \\
Pengambilan Keputusan & Sig. (2-tailed) & 0.022 & 400 \\
& N & 400 & \\
\hline
\end{tabular}

Berdasarkan tabel 4.15 diketahui bahwa nilai koefisien korelasi positif sebesar 0.561 dengan taraf signifikan (p) senilai $0.022(p<$ 0.05 ) sehingga hipotesis yang diajukan penulis dapat diterima karena terdapat hubungan positif yang signifikan antara variabel BigFive Personality Neuroticsm dengan Pengambilan Keputusan Dalam Memilih Parfum. Terlihat nilai signifikansi korelasi pearson dengan nilai 0.561 , hal ini menunjukkan jika korelasi antara BigFive personality Neuroticsm dengan Pengambilan Keputusan memiliki korelasi yang sedang.

Tabel 4.16

Hasil Uji Determinasi

\begin{tabular}{ccccc}
\hline Model & $\mathrm{R}$ & $\begin{array}{c}\mathrm{R} \\
\text { Square }\end{array}$ & $\begin{array}{c}\text { Adjusted } \\
\mathrm{R} \\
\text { Square }\end{array}$ & $\begin{array}{c}\text { Std. Error } \\
\text { of the } \\
\text { Estimate }\end{array}$ \\
\hline $\begin{array}{c}\text { BigFive } \\
\text { Personaltiy }\end{array}$ & 0.339 & 0.329 & 0.281 & 6.292 \\
\hline
\end{tabular}

Berdasarkan tabel 4.16 diketahui bahwa diperoleh nilai $\mathrm{R}$ Square sebesar 0.329 dapat disimpulkan bahwa bigfive personality memiliki sumbangsih sebesar $32.9 \%$ terhadap pengambilan keputusan.

Hasil deskriptif data penelitian, dari 400 subjek yang diambil, diketahui subjek yang mengalami permasalahan dalam pengambilan keputusan berada dalam kategori tinggi berjumlah 117 orang atau sebesar $29.3 \%$. Untuk subjek yang memiliki tingkat kepribadian BigFive Personality terbesar terdapat dalam kategori sedang, berjumlah 187 orang atau sebesar $46.8 \%$.

Besarnya hubungan tersebut dapat diketahui melalui analisis korelasi Product Moment memperoleh koefisien korelasi (r) sebesar 0.839 dengan nilai $p$ sebesar $0,035 \quad(p<0.05)$. Untuk faktor Openness, memperoleh koefisien korelasi (r) sebesar 0.600 dengan nilai $p$ sebesar 0,045 $(p<0.05)$. Untuk faktor Conscientiousness memperoleh koefisien korelasi (r) sebesar 0.514 dengan nilai $p$ sebesar $0,015 \quad(p<0.05)$. Untuk faktor Agreeableness memperoleh koefisien korelasi (r) sebesar 0.551 dengan nilai $p$ sebesar $0,002 \quad(p<0.05)$. Untuk faktor Extraversion memperoleh koefisien korelasi (r) sebesar 0.542 dengan nilai $p$ sebesar $0,040(p<0.05)$. Dan untuk faktor Neuroticsm memperoleh koefisien korelasi (r) sebesar 0.561 dengan nilai $p$ sebesar 0,022 $(p<0.05)$.

Berdasarkan hasil uji asumsi sebaran data variabel BigFive Personality berdistribusi normal dengan nilai $p=0.165(p>0,05)$. Sementara hasil uji asumsi sebaran data variabel keterampilan Pengambilan Keputusan normal dengan nilai $p=$ 0.124. Selanjutnya, dari penelitian yang sudah dilakukan diketahui bahwa terdapat hubungan yang linier antara variabel bebas dan juga variabel terikat dengan nilai $p=0.387(p>0,05)$.

Karakter Openness dan Agreeableness dalam memilih parfum cenderung menerima sugesti dari orang sekitar terhadap harga produk serta kemasan produk, namun, karakter Agreeableness lebih mempertimbangkan status sosial seperti pembelian parfum dengan harga yang mahal ataupun merk terkenal. Conscientiousness merupakan karakter yang teliti dalam membeli parfum, sehingga karakter ini lebih meninjau dari segi harga, seperti dalam pembelian promo parfum. Karakter Neuroticism merupakan karakter yang khawatir atau cemas, ketika membeli parfum, karakter ini cenderung untuk meninjau harga parfum sebelum membeli, karakter Extraversion merupakan karakter yang tegas dalam membeli parfum, karakter ini cenderung membeli parfum dengan mengambil keputusan yang rasional, seperti dalam pembelian parfum, meskipun terdapat sebuah promo parfum ataupun diskon, ketika karakter ini tidak 
membutuhkannya, maka mereka tidak membeli parfum tersebut.

\section{SIMPULAN}

Pentingnya untuk mengenali dan memahami dalam pengambilan keputusan dalam membeli parfum dan faktor apa yang mempengaruhi konsumen dalam proses pengambilan keputusan. Konsumen parfum memang telah membuat keputusan tentang pilihan, pembelian dan penggunaan produk setiap saat. Keputusan ini juga memang cukup penting bagi konsumen maupun bagi pemasar. Parfum tertentu dapat menghasilkan perasaan dan suasana hati tertentu yang merupakan faktor situasional yang mempengaruhi proses pengambilan keputusan. Lingkungan fisik juga mempengaruhi perilaku konsumen menurut lokasi toko, musik, bau dan aroma. Selain itu, adanya hubungan yang kuat antara kepribadian Big Five Personality dengan pengambilan keputusan. Hal ini berkorelasi tinggi antara kelima faktor dengan pengambilan keputusan dalam memilih parfum. Akan tetapi, jika kepribadian Openness lebih terbuka dalam mengambil keputusan, selain karakter Openness, karakter lainnya ialah Extraversion dimana, karakter ini lebih cenderung bebas dalam memilih keputusan. Pemilihan keputusan bisa diilustrasikan sebagai tujuan untuk meyakinkan diri konsumen dalam memilih sebuah pilihan dalam memilih parfum. Hal ini juga memiliki sisi positif ataupun sisi negatif. Jika salah memilih parfum, maka konsumen bisa saja menerima dampak negatifnya seperti jenis cairan yang tidak cocok ataupun aroma yang terlalu kuat hingga membuat orang sekitar merasa tidak nyaman dengan kehadiran konsumen.

\section{SARAN}

Pemilihan parfum, konsumen tentunya juga bisa dihadapkan dengan pemilihan parfum, hal tersebut tentu memiliki strategi untuk memilih parfum yang dirasa cocok bagi karakter konsumen. Dalam pengambilan keputusan, selalu ada dasar qualitatif dalam menentukan pilihan, misalkan jika konsumen ingin membeli sebuah parfum, maka konsumen tersebut mendapat sugesti ataupun bertanya kepada penjual parfum dengan mencari informasi yang dibutuhkan dalam memilih parfum. Jika dihadapkan oleh dua pilihan, individu memilih aroma yang cocok ataupun aroma yang sesuai dengan karakter dari diri individu pemakai parfum yang kemungkinan memiliki hubungan dengan tipe kepribadian.

\section{DAFTAR PUSTAKA}

Amira Srour Abusrour. (2016). Factors Affecting Consumers' Choice of Perfume Products: The Case of Famagusta - North Cyprus. Master of Arts in Marketing Management. Diunduh 29.03.2020 https://www.researchgate.net/

Costa P. T. and McCrae R. R. (1992). Revised NEO personality inventory (NEO-PI-R) and $N E O$ five-factor (NEO-FFI) inventory professional manual, Odessa, FL: PAR. Diunduh 01.04.2020 dari New York: Guilford Press.

Krestin Pezodlt. (2016). Ilmenau University of Technology Department of Marketing Faculty of Economics. Department of Marketing Faculty of Economics. Diunduh 30.03.2020 https://www.researchgate.net/

McCrae, R. R., and Costa, P. T., Jr. (1998). Toward a new generation of personality theories: Theoretical contexts for the fivefactor model. In J. S. Wiggins (Ed.). The Five-factor model of personality: Theoretical perspectives (hal. 51-87). Diunduh 29.03.2020 dari New York: Guilford.

Pavlina (2012). 5 Lessons We Learned from 'Mobilegeddon'. Forbes. Diunduh 30.03.2020.

http://www.forbes.com/sites/jaysondemers/ 2015/05/11/5-lessons-we-learned-frommobilegeddon/\#2b3b2b721db4

Sabine, Scezny. (2015). Do-It-Yourself Perfume. Thanh Nien Tuan San. Economic Department 30.03.2015. Diunduh 29.03.2020 http://thanhnien.vn/doi-song/tupha-che-nuoc-hoa-626684.html

Statista Research Department (2018). Diunduh 30.03.2020

https://www.statista.com/statistics/ 231406/people-who-bought-cosmetics-inthe-last-12-months-usa/

Sugiyono, (2010). Statistika Untuk Penelitian, PT. Alfabeta, Jawa Barat, ISBN: 979-8433-10-6 